\title{
THE GENESIS OF PEROVSKITE-BEARING BEBEDOURITE AND THE PROBLEMS POSED BY CLINOPYROXENITE-CARBONATITE COMPLEXES.
}

\author{
LLoyd, F.E. and Bailey, D.K.
}

Dept. Geology, Univ. Bristol, Wills Memorial Building, Queens Rd., Bristol BS8 1RJ, UK.

Bebedourite (Ti-rich, perovskite-titanomagnetite-apatitephlogopite clinopyroxenite) is an early-formed facies of 91-70 Ma pyroxenite-carbonatite complexes emplaced in a zone of deep-seated faults between the Parana Basin and the Sao Francisco Craton, Brazil. Late-stage carbonatite cores are $\mathrm{Nb}$ and REE rich and compare closely with Iron Hill, Colorado, but South African clinopyroxenite-carbonatites, e.g. Phalaborwa, are by contrast poor in these elements.

Type bebedourite from the base of Salitre 1 borehole $(114 \mathrm{~m})$ does not show typical cumulus texture. Large (ca. $6 \mathrm{~mm}$ across) isolated, coarse aggregates or single grains of diopside are heavily fractured,.corroded, fluid-inclusion filled, and "supported" in a coarse matrix. Matrix minerals crystallised in the order: first-generation phlogopite, fluor-apatite, magnetite which both rims and forms inclusions in Ceperovskite, followed by Ce-perovskite and titanomagnetite. Diopside rims are partly replaced by phlogopite, and typically a narrow band of second generation phlogopite + a carbonated alkali-mafic silicate mineraloid separates diopside from adjacent minerals. Corroded areas and cleavages in diopside are variously filled by phlogopite flakes, apatite, occasional perovskite grains, and veinlets + blebs of the carbonatesilicate mineraloid. Electron microprobe investigation has revealed areas where the mineraloid can be resolved into calcite, K-richterite and a serpentine-like material.

Diopsides are homogeneous, nearly pure (woll 50, en 44, fs 6), and low in $\mathrm{Cr}_{2} \mathrm{O}_{3}$ (below detection-0.08 wt\%), $\mathrm{TiO}_{2}(0.72-1.06$ wt\%), $\mathrm{Al}_{2} \mathrm{O}_{3}\left(0.47-0.41\right.$ wt\%), and $\mathrm{Na}_{2} \mathrm{O}(0.26-0.35$ wt\%), characteristics shared by pyroxenes from lamproites (Mitchell, 1979; Hamilton and Rock, 1990) and pyroxenite facies of other pyroxenite-carbonatite complexes e.g. Iron Hill, Colorado. Kimberlite groundmass clinopyroxene (Dawson et al., 1977) has slightly less $\mathrm{TiO}_{2}$, lower $\mathrm{MgO} / \mathrm{FeO}$ values and higher $\mathrm{Cr}_{2} \mathrm{O}_{3}$. Petrography indicates that the bebedourite diopside is more primary than the mineral assemblage in which it occurs and is possibly xenocrystic in origin. Such clinopyroxene does not have necessarily any evolutionary relationship with the more $\mathrm{Fe}-$ and $\mathrm{Na}-\mathrm{rich}$ clinopyroxenes of rocks consanguineous with some clino-pyroxenites such as pyroxene sovites, ijolites and syenites.

First-generation phlogopite $(\mathrm{Mg} /(\mathrm{Mg}+\mathrm{Fe})=0.88)$ is aluminous. Second-generation phlogopite is peralkaline $\left(\mathrm{Mol} . \mathrm{K}_{2} \mathrm{O}+\mathrm{Na}_{2} \mathrm{O} / \mathrm{Al}_{2} \mathrm{O}_{3}\right.$ up to 10.7 ) and trends towards tetraferriphlogopite. In contrast with phlogopites in lamproites $\mathrm{TiO}_{2}$ is low in both types. On an $\mathrm{Al}_{2} \mathrm{O}_{3}$ vs $\mathrm{TiO}_{2}$ diagram (after Mitchell, 1985) the first generation plots in the field of phlogopites from kimberlites which also overlaps with the 
Leucite Hills lamproite field. The second generation defines a kimberlitic ( $\mathrm{TiO}_{2}$-poor), as opposed to lamproitic, trend. Low $\mathrm{Cr}_{2} \mathrm{O}_{3}$ in the bebedourite phlogopites, however, is more typical of lamproite than kimberlite phlogopites (Hamilton and Rock, 1990). The suggestion that increasing $\mathrm{Fe}^{3+}$ in phlogopite relates to increasing $\mathrm{K}_{2} \mathrm{O}+\mathrm{Na}_{2} \mathrm{O} / \mathrm{Al}_{2} \mathrm{O}_{3}$ in the liquid (Velde and Yoder, 1977) is consistent with the composition of the interstitial residue (mineraloid + K-richterite).

Perovskites are close to pure composition (average wt\% $\mathrm{TiO}_{2}=$ $56.4 ; \mathrm{CaO}=39.7)$ with low $\mathrm{FeO}(<1.5$ wt\% $), \mathrm{Na}_{2} \mathrm{O}(<0.5$ wt\%) and, apart from $\mathrm{CeO}(>1 \%)$, relatively low $\mathrm{REE}^{2}$ and $\mathrm{Nb}$ content. In these respects they are typical of perovskites from kimberlites and alkali-mafic lavas and contrast with those from lamproites and carbonatites which show considerable ss towards loparite and leushite end-members (Mitchell, 1985).

In magnetite $\mathrm{TiO}_{2}$ is $<1$ wt\%; MgO varies from below detection to $2.4 \mathrm{wt} \% \mathrm{Al}_{2} \mathrm{O}_{3}, \mathrm{Cr}_{2} \mathrm{O}_{3}$ and $\mathrm{MnO}$ are all<0.5 wt\%, a composition that compares closely with an analysis given for magnetite surrounding perovskite in the Premier magnetiteserpentine-carbonate dikes (Mitchell, 1979). Titanomagnetite (average wt\% $\mathrm{TiO}_{2}=26$ ) contains 2.1-4.04 wt\% MnO which is comparable to carbonatite magnetites (Mitchell, 1979), but the considerable ulvospinel component is much more typical of $\mathrm{Mn}$ bearing magnetites in alkali-mafic lavas, e.g. SW Uganda (Lloyd et al., in press).

The carbonated silicate contains variable $\mathrm{SiO}_{2}$ (22-38 wt\%), $\mathrm{MgO}(8-13 \mathrm{wt} \%)$ and $\mathrm{CaO}(22-33 \mathrm{wt} \%) ; \mathrm{TiO}_{2}$ and $\mathrm{Al}_{2} \mathrm{O}_{3}$ are $<1$ wt\%. Apart from high alkalis: $\mathrm{Na}_{2} \mathrm{O} \bumpeq \mathrm{K}_{2} \mathrm{O}=\mathrm{ca} .3 \mathrm{wt} \%$, the composition is comparable to calcite kimberlites such as the Premier magnetite-serpentine-calcite dikes. Where blebs of calcite occur the Sr-content of $>1 \%$ implies a primary origin. Associated $K$-richterite has a composition very close to that found in MARID xenoliths (Dawson and Smith, 1977) with $\mathrm{Mg} /(\mathrm{Mg}+\mathrm{Fe})=90, \mathrm{~K} 2 \mathrm{O} \approx \mathrm{Na} 2 \mathrm{O}=\mathrm{ca} \cdot 5 \mathrm{wt} \%$, and $\mathrm{TiO}_{2}$ not $>0.75$ wt\% distinguishing it from Ti-bearing richterites in lamproites and K-mafic lavas (Mitchell, 1985).

On the basis of petrography and mineral chemistry bebedourite may represent clinopyroxene-rich mantle invaded and mobilised by a kimberlite-carbonatite melt. The clinopyroxenite mantle facies could originate as the product of partial melting in the sub-cratonic mantle on a geothermal gradient where clinopyroxene, but not phlogopite and calcite, is stable, i.e, just above the Wendlandt and Eggler solidus. Such a melt could accumulate, become gravitationally unstable and slowly rise, crystallising clinopyroxene en-route. In terms of heat balance, however, the P-T path could be expected to remain close to and subsequently reapproach the solidus, (Bailey, 1986) limiting upward movement and causing stagnation. These conditions would encourage the separation of volatile-rich, alkali-mafic silica-calcite fluid/melt. This pegmatitic medium, pervasively injected, could effect the paracontemporaneous auto-remobilisation of part of the clinopyroxenite body as a "mush" of clinopyroxenes with 
xenocrystic appearance. A proportion of the clinopyroxenes would be likely true xenocrysts from the products of previous like episodes of diapir stagnation. Eventual emplacement of the crystal mush within the crust would be the consequence of concentrated channeling of the volatile-rich medium beneath a major crustal fault zone.

Phlogopite, apatite and magnetite would precipitate from the pegmatitic medium and late-stage enhanced $\mathrm{CO}-\mathrm{CO}_{2}$ activity would encourage $\mathrm{Ti}$ activity and cause precipitation of $\mathrm{Ti}-$ minerals in an otherwise Ti-poor assemblage.

The diapiric upward movement of the clinopyroxene "crystal mush" to lower $\mathrm{P}, \mathrm{T}$ regions could lead to separation and eventual emplacement of an immiscible carbonatite magma.

The bebedourite diopside lacks features that popularly might be expected to imply mantle affinity, i.e. Cr, jadeite, Tschermak's molecule. This raises a question about the nature of the possible mantle source. Another question is the origin of the $\mathrm{Nb}$ - and REE-rich signature of the associated carbonatite cores and whether this endorses a kimberlitic connection. Both these questions are being investigated and possible answers will be proposed.

References.

Bailey, D.K. (1986) Fluids, melts, flowage and styles of eruption in alkaline ultramafic magmatism. In Alkaline and alkaline ultrabasic rocks and their xenoliths. Transactions of the Geological Society of South Africa, Special Issue, 88, 449-458.

Dawson, J.B., and Smith, J.V. (1977) The MARID (micaamphibole-rutile-ilmenite-diopside) suite of xenoliths in kimberlite. Geochimica Cosmochimica Acta, 41, 309-323.

Dawson, J.B., Smith, J.V., and Hervig, R.L. (1977) Late stage diopsides in kimberlite groundmass. Neues Jahrbuch fur Mineralogie Monatsheft, 12, 529-543.

Hamilton, R., and Rock, N.M.S. (1990) Geochemistry, mineralogy and petrology of a new find of ultramafic lamprophyres from Bulljah Pool, Nabberu Basin, Yilgarn Craton, Western Australia. Lithos, 24, 275-290.

Lloyd, F.E. (1991) Phanerozoic volcanism of southwest Uganda: a case for regional $K$ and LILE enrichment of the lithosphere beneath a domed and rifted continental plate. In A.B. Kampunzu and R.T. Lubala, Eds., Phanerozoic extensional magmatism and structural evolution of the African plate, p. 23-72. Springer-Verlag, Heidelberg, in press.

Mitchell, R.H. (1979) The alleged kimberlite-carbonatite relationship: additional contrary mineralogical evidence. American Journal of Science, 279, 570-589.

Mitchell, R.H. (1985) A review of the mineralogy of lamproites. Transactions of the Geological Society of South Africa, 88, 411-437.

Velde, D., and Yoder, H.S. (1977) Melilite and melilitebearing igneous rocks. Carnegie Institution of Washington Yearbook, 76, 478-485. 